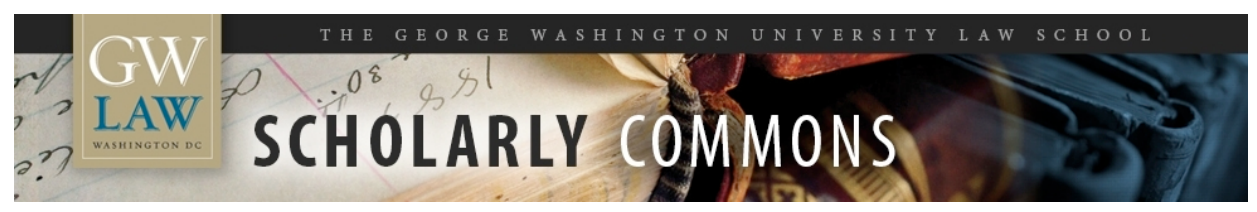

\title{
Beyond Invisibility: Afro-Argentines in Their Nation's Culture and Memory
}

Robert J. Cottrol

George Washington University Law School, bcottrol@law.gwu.edu

Follow this and additional works at: https://scholarship.law.gwu.edu/faculty_publications

Part of the Law Commons

\section{Recommended Citation}

Robert J. Cottrol, Beyond Invisibility: Afro-Argentines in Their Nation's Culture and Memory, 42 Latin Amer. Res. Rev., (2007)

This Article is brought to you for free and open access by the Faculty Scholarship at Scholarly Commons. It has been accepted for inclusion in GW Law Faculty Publications \& Other Works by an authorized administrator of Scholarly Commons. For more information, please contact spagel@law.gwu.edu. 


\title{
REVIEW ESSAYS
}

\author{
BEYOND INVISIBILITY \\ Afro-Argentines in Their Nation's \\ Culture and Memory*
}

Robert J. Cottrol

George Washington University

BUENOS AIRES NEGRA: ARQUEOLOGÍA HISTÓRICA DE UNA CIUDAD SILENCIADA. By Daniel Schávelzon (Buenos Aires: Emecé Editores, 2003. Pp. 209. \$22.10 paper.)

THE AFRO-ARGENTINE IN ARGENTINE CULTURE: EL NEGRO DEL ACORDEÓN. By Donald S. Castro. (Lewiston, NY: The Edwin Mellen Press, 2001. Pp. iii+185. \$109.95 cloth.)

IDENTIDADES SECRETAS: LANEGRITUD ARGENTINA. By Alejandro Solomianski. (Rosario, Argentina: Beatriz Viterbo Editora, 2003. Pp. 267. $\$ 15.00$ paper.)

The study of Afro-Argentines has long presented something of a paradox. The field has frequently received inadequate attention from both students of Argentine history and from scholars concerned more generally with the issue of race in the Americas. This neglect has been partially fueled by the prevailing racial ideology in twentieth-century Argentina-namely that the nation is not only white, but indeed fundamentally European. That view has been buttressed by large-scale European immigration to

* The author would like to acknowledge helpful comments made by Jonathan Bush and Pablo J. Davis, who read earlier drafts of this essay.

Latin American Research Review, Vol. 42, No. 1, February 2007

(C) 2007 by the University of Texas Press, P.O. Box 7819, Austin, TX 78713-7819 
the nation since the end of the nineteenth century. Academic neglect was also fueled by the conventional wisdom that in the twentieth century, the Afro-Argentine population had ceased to exist as a numerically significant group. The Argentine Census of 1895 recorded a black population of 5,000. By 1954 Argentine social scientist Angel Rosenblat, in what he admitted were hypothetical figures, indicated that Argentina had a population of 5,000 blacks and 10,000 mulattoes in an overall population of roughly 17 million. U.S. Argentinianist James Scobie would state in 1964 that even that low estimate was probably too high. ${ }^{1}$ Although there is a popular belief that Argentina never had a significant African presence, historians of Argentina know better, realizing that Buenos Aires was a major center for slave importation and that throughout the nineteenth century, Africans and their Afro-Argentine descendants were significant percentages of the population of Buenos Aires and other Argentine regions. The view is that the Afro-Argentine population disappeared by the twentieth century, the result of Argentina's nineteenth-century wars and the Yellow Fever Epidemic of 1871, and that little in the way of an enduring presence remains either in terms of population or lingering cultural influence. This traditional view was captured in a statement by former Argentine President Carlos Menem who once declared: "In Argentina blacks do not exist, that is a Brazilian problem." 2

Yet paradoxically there has also persisted in the twentieth century an undercurrent of national interest in Afro-Argentines, belying their supposed irrelevance to the development of the national culture. The 1924 publication of Memorias de un negro del congreso told the story of one member of a group of highly visible Afro-Argentines, congressional porters and doormen-a

1. Ángel Rosenblat: La población indígena y el mestizaje en America, Vol 1, La población indígena, 1492-1950, (Buenos Aires: Editora Nova, 1954), 21-22, 170; James R. Scobie, Argentina: A City and a Nation, Second Ed. (New York: Oxford University Press, 1971), 33. Rosenblat was very aware of the tentative nature of racial categories found in official statistics. He noted that "the lines between Indian, mestizo and white or between black, mulatto and white are very unstable and the census taker has to quickly determine on his own that which would take much time and effort on the part of a professional anthropologist. The criteria also changes from one country to another. Surely half of those who are classified as mestizo in Mexico would pass for pure whites in Brazil and other countries.... In the United States a Negro is one who has a drop of black blood; in Latin America a white is one who has one drop of white blood. More than reality, statistics reflect the ideals of each nation or the aspirations of its inhabitants." Rosenblat, La población indígena, 19 (my translation).

2. This statement is noted in the documentary film "Afroargentinos" (Diego H. Ceballos et al., directors, 2005), an exploration of contemporary Afro-Argentine life in Buenos Aires. The film shows the quote and also ironically has Menem posing for a picture with Horacio Pita, an Afro-Argentine who works as a congressional orderly, one of the few jobs with high visibility traditionally available to Afro-Argentines. Pita was profiled in the Buenos Aires daily La Nación in April 2004. See "Raíces africanas en el Congreso: Horacio Pita y una tradición de 136 años, La Nación 7 de abril de 2004, p. 8, sec 4. 
congressional hiring practice that began in the late nineteenth century and continues to the present. In 1926 Uruguayan-born Argentine writer Vicente Rossi published the folkloric Cosas de negros. Despite the book's often paternalistic racism, it did serve to remind Argentine audiences of the often pronounced impact Afro-Argentines had had on the nation's culture before the twentieth century. Rossi was particularly important for reminding a then very European-oriented Argentina of the African roots of the tango. Also, Argentine artist Antonio Berni routinely included black, mulatto, and mestizo figures in his paintings, depicting the everyday lives of the Argentine working class. ${ }^{3}$

Interest in Afro-Argentines increased from the 1960s onward, spurred on, at least in part, by international events: the civil rights movement in the United States, the emergence of independent nations in Africa, the struggle against apartheid in South Africa, the emergence of a more assertive Afro-Brazilian movement, and a growing resistance to traditional patterns of making Latin Americans of African descent invisible. It thus became a topic for occasional explorations by Argentine and foreign journalists. ${ }^{4}$ The field began to gain heightened academic visibility in the 1970s and 1980s, aided in part by the scholarship of Argentine historians such as Marta Goldberg and Ricardo Rodriguez Molas and North American historians such as Leslie Rout and George Reid Andrews. ${ }^{5}$

That new visibility grew in the 1990s and beyond, aided by Argentine scholars influenced by Afro-Americanist research in the United States, Brazil, and other American nations. Interest in the field also increased due to a new willingness among Afro-Argentines to publicly and vocally resist traditional patterns of marginality and invisibility and to press the case that their group's history be added to the national narrative. By the beginning of the twenty-first century even the Argentine government was beginning to show more of an official interest in Argentina's Afro-American past. At

3. Mamerto Fidel Quinteros, Memorias de un negro del congreso, (Buenos Aires: Talleres Gráficos Argentinos de L. J. Rosso, 1924); Vicente Rossi, Cosas de Negros, (Buenos Aires: Taurus, 2001). Among the paintings in which Berni included what appear to be AfroArgentine and mestizo subjects are Desocupados (1934), Chacareros (1935), Orquesta típica (1939), La comida (1953), Team de football o campeones del barrio (1954), and Escuelita rural (1956). These may be seen in Fermín Fêvre, Berni (Buenos Aires: Editorial El Atneo, Bifronte, 2001). Other Berni paintings with Afro-Argentine figures include El obrero caído (1953) and La manfestación (1934).

4. Máximo Simpson, "Porteños de color," Panorama (June 1967), 78-85; Luis Grassino, "Buenos Aires de ebano," Revista Clarín, (December 5, 1971), 34-39; Era Bell Thompson, "Argentina, Land of the Vanishing Blacks," Ebony (October, 1973), 74-85.

5. Marta B. Goldberg, "La población negra y mulata de la Ciudad de Buenos Aires, 1810-1840." Desarrollo Económico, vol. 16 (April-June, 1976), 75-99; Leslie B. Rout, Jr. The African Experience in Spanish America, 1502 to the Present Day (New York: Cambridge University Press, 1976); George Reid Andrews, The Afro-Argentines of Buenos Aires, 1800-1900 (Madison: University of Wisconsin Press, 1980). 
the behest of Afro-Argentine activists, a monument was dedicated to AfroArgentine soldiers of the nineteenth century. In 2002, President Eduardo Luis Duhalde wrote a prologue to a government-sponsored reprinting of Afro-Argentine Jorje M. Ford's Beneméritos de mi estirpe: Esbozos sociales, a book written in 1899 giving short biographies of notable nineteenth-century Afro-Argentines. The Argentine Library of Congress currently runs a Web site devoted to the history of race and slavery in Argentina and Uruguay. ${ }^{6}$

It is in this new twenty-first century atmosphere of greater receptivity to academic investigations of Afro-Argentine life that Schávelzon's Buenos Aires negra, Castro's The Afro-Argentine in Argentine Culture and Solomianski's Identidades secretas have been published. All three studies raise new issues concerning the role of Afro-Argentines in the national culture, the connections between the Afro-American experience in Argentina and in other parts of the hemisphere, and the ways in which modes of cultural expression, both material and literary, may help us to understand larger and often hidden patterns of social structure and social interaction.

6. Argentine social anthropologist Alejandro Frigerio is an important example of an Argentine scholar influenced by Afro-Americanist scholarship in Brazil and the United States. See Alejandro Frigerio, Cultura negra en el cono sur: Representaciones en conflicto (Buenos Aires: Ediciones de la Universidad Católica Argentina, 2000). Other works that indicate the increased scholarly interest in the field in the last decade include: M. Cristina de Liboreíro No hay negros argentinos? (Buenos Aires: Editorial Dunken, 1999); El negro en la Argentina: Presencia y negación, Dina V. Picotti, comp., (Buenos Aires: Editores de América Latina, 2001) and Marvin A. Lewis, Afro-Argentine Discourse: Another Dimension of the Black Diaspora (Columbia, Mo.: University of Missouri Press, 1996). The emergence of new voices from Afro-Argentine communities in the last decade has been particularly important in the effort to bring to light both the history of Afro-Argentines and their current circumstances. Three women have been particularly important in their communities' struggles against invisibility and racial subordination. Lucía Dominga Molina, a descendant of Argentine slaves living in Santa Fe, Argentina, heads La Casa de la Cultura Indo-Afro-Americana in that city. It houses a library on Afro-Argentine history and has participated with the city of Santa Fe in putting on plays devoted to Afro-Argentine history. In 2004 she wrote a short essay discussing stigmatization of current Afro-Argentines "El negro en una sociedad pretendidamente blanca" (available at http:/ / alainet.org/org/active/show_text.php3?key=1006). María Magdelena de la Madrid, also a descendant of Argentine slaves, heads a grassroots community organization in Buenos Aires, "Fundación Africa Vive" (http:/ / www.africavive. org.ar/index2.htm). She played a key role in getting the government to dedicate the monument. Miriam Gomes, a descendant of Cape Verdean immigrants, is particularly important as an Afro-Argentine who is a part of her nation's academic life. A specialist in Lusophonic literature, she has taught at Argentina's Pontifical University and the University of Buenos Aires and has written broadly on Afro-Argentine history and sociology. See, for example, Miriam V. Gomes, "Apuntes para una historia de las instituciones negras en la Argentina," in Dina V. Picotti, comp., El negro en la Argentina: Presencia y negación, 401-428. Duhalde's prologue may be found in Jorje M. Ford, Beneméritos de Mi Estirpe: Esbozos Sociales (Buenos Aires: Catálogos, 2002). 
Schávelzon brings the perspective of a historical archaeologist who has long studied the urban archaeology of Buenos Aires to the investigation of African and Afro-American life in that city in the nineteenth century. Schávelzon's investigations had their genesis in conversations with University of South Carolina historical archaeologist Leland Ferguson, who suggested that historical archaeology, with its ability to consider material remains as well as narrative sources, could broaden and deepen our understanding of the otherwise often anonymous slaves, libertos, and free Afro-Argentines of the nineteenth century. This use of archaeological method to leaven otherwise sparse narrative sources and increase our understanding of the lives of peoples of African descent in the Americas was already a well developed study in the United States, the British West Indies, Brazil, and other locations. ${ }^{7}$

Schávelzon wants to use his interdisciplinary focus in part to demolish some longstanding Argentine myths. He challenges traditional views that slavery was never economically important and that Argentina only received "the best Africans," who became docile and contented slaves leading comparatively comfortable lives as house servants indulged by kindly masters. Finally, Schávelzon is interested in taking on the stereotype that Africans had only a minimal impact on Argentine culture, were empty vessels for the superior Spanish culture, and that African and AfroArgentine culture can be safely dismissed as silly cosas de negros. Drawing on existing historiography, primary sources, and excavations done at two sites, Schávelzon constructs an alternative portrait of a nineteenth-century Buenos Aires with a strong and vibrant African culture preserved, in part, as a silent challenge to Spanish hegemony and African subordination. Particularly at the beginning of the nineteenth century, various modes of African cultural expression were found throughout the city. This was aided by a large percentage of people of African descent in Buenos Aires, a reported and probably undercounted 30 percent of the total population, since at the beginning of the nineteenth century a significant percentage of that population was African-born with relatively recent African memories. The city was awash with African nations, organized along ethnic or putative ethnic lines. These evolved out of African brotherhoods that had been sponsored by the Church in the eighteenth century. Afro-Porteños spoke the syncretic 'Bozal' patois rather than pure Spanish. There were barrios del tambor where drums played, Candombe was danced, and few whites dared enter. African burial rituals were practiced and African forms of cooking along with African cookware, pipes, and other artifacts were preserved. ${ }^{8}$

7. Schávelzon at 13, 24; C. E. Orser, Jr., "The Archaeology of the African Diaspora," Annual Review of Anthropology vol. 27 (1998), 63-82.

8. Andrews, The Afro-Argentines of Buenos Aires, 68-71. 
Schávelzon's discussion of Afro-Argentine cultural influence takes us beyond Buenos Aires into an examination of the African presence in the interior. At the end of the eighteenth century, Tucumán, Santiago del Estero, Catamara, Salta, and Córdoba averaged well over 50 percent African-descended populations. One important part of this discussion hints at the syncretism of African and indigenous cultures. Here Schávelzon is tantalizing. We get brief discussions of the importance of this mixture and are informed that it was widespread and that the synthesis of peoples and cultures was strong, even producing Quechuaspeaking Afro-Argentines in the Northwest. It is an important, if brief, discussion - a reminder that throughout the Americas Africans and their Afro-American descendants played a critical role in mestizaje, in many cases more important than the role of whites. The issue of the cultural and physical mixture of African and indigenous peoples, which has been understated in the literature on race in Argentina, has a twofold importance. First of all, it is an important part of the history of cultural synthesis in Argentina. What role did Africans and their descendants have in transmitting elements of both African and Spanish cultures to the indigenous and later mestizo populations of the nation? The formation of Afro-mestizo populations is also one critical element in the demographic puzzle of why the large Afro-Argentine population of the nineteenth century became invisible in the twentieth.

However, it is the place of Afro-Argentines and their struggle to define their culture and carve out a place for themselves in nineteenth-century Buenos Aires that occupies most of Schávelzon's attention. Schávelzon's Buenos Aires at the beginning of the nineteenth century is emerging only slowly from the rather harsh slave regime of the previous century. If manumissions had been common, they were less a result of paternalistic benevolence and more because the urban economy, as was the case elsewhere in the Americas, provided opportunities for slaves to earn money to buy their freedom. A large number of manumitted slaves were aged and infirm, essentially discarded in the last years of life. Branding of slaves was common. Slave auctions were held throughout the city, including auctions in a large slave market in Lezama Park in the modern neighborhood of San Telmo.

Slavery would die a painfully slow death in nineteenth-century Buenos Aires. Clandestine importation of slaves occurred after the passage of the 1813 "Law of the Free Womb." Many slaves found that manumission was highly conditional and often dependent on military service. Many Afro-Argentines would remain dependent on patron-client relations with elite whites well into the nineteenth century, even after slavery was abolished in $1861 .^{9}$ 
Schávelzon takes the reader through the major themes of nineteenthcentury Afro-Argentine history, including their high participation in the nation's wars, their alliance with and allegiance to Federalist dictator Juan Manuel de Rosas, their critical role in the formation of gaucho culture, and the impact of the 1871 Yellow Fever epidemic on the community. Schávelzon is quite aware that much of the discussion of the so-called disappearance of the Afro-Argentines began in the middle of the nineteenth century while blacks and mulattoes were still a significant and indeed visible part of the national population. That discussion, more aspirational than factual, was tied to a combination of factors, chief among them the scapegoating of Afro-Argentines as one of the more visible and vulnerable groups of the populist coalition that had supported Rosas. That combined with the desire of liberal reformers such as Domingo Faustino Saramiento to create a modern, progressive Argentine nation by replacing what they saw as the inferior creole population, with its embarrassing African and Indian elements, with racially superior European immigrants, fueled the desire to see the Afro-American, Indian, and mestizo populations as vanishing species. This idea of building new nations in the Americas by exchanging the large brown populations that were legacies of the colonial era for white populations that would presumably triumph in nature's Darwinian struggle for survival in the twentieth century was gaining popularity among national elites throughout Latin America toward the end of the nineteenth century. Blanqueamiento through encouraging immigration and deemphasizing the African- and indigenous-descended populations would become national policy in Brazil, Cuba, Venezuela, and other American nations, including and perhaps especially in Argentina. ${ }^{10}$

Throughout his exploration of the nineteenth-century Afro-Porteño world, Schávelzon retains his concern with the theme of African culture and its preservation. The question of African survivals in the Americas is, of course, an old one that has been examined from a number of disciplinary and ideological perspectives. The field has all too often been overshadowed by an acceptance of the essentially Darwinist premises of early twentieth-century scholars-that evidence of the survival of African cultures in New World societies is necessary to establish that those cultures were not inferior to the dominant European cultures. Happily, I think, there is now a much greater willingness among historians and social scientists to recognize the complexity of the African survival question, its contingency on demographic, geographic, and other historical

10. Alejandro de la Fuente, A Nation for All: Race Inequality and Politics in Twentieth Century Cuba (Chapel Hill: University of North Carolina Press, 2001) pp 44-53. Petrônio Domingues, Uma história nâo contada: Negro, racismo, e branqueamento em Sâo Paulo no pós-aboliçâo (Sâo Paulo: Editora Senac, 2004) 253-256. 
variables, and the importance of understanding the syncretism of African, European, and indigenous cultures in the Americas. ${ }^{11}$

Schávelzon is aware of these complexities, and although he presents a rich array of African artifacts and Argentine paintings depicting AfroAmerican participation in Porteño society, he is aware that material evidence can raise as well as answer questions. If African pipes and pottery can be found in burial grounds and other excavation sites, there still remains the task of assessing their cultural significance. Were they brought from Africa, indicating perhaps fading memories of an aging African-born population? Or were they made by Afro-Argentines, indicating the transmission of African cultural patterns to new generations? Were these African utensils used exclusively or even primarily by people of African descent? Or did they play a role in the kind of cultural diffusion that occurred in the linguistic arena where Spaniards, Africans, and Indians all at times shared and adopted to varying degrees the languages or fragments of the languages of the other groups? Here Buenos Aires negra shows the contribution that historical archaeology can make to the study of African and Afro-American cultures in the Americas. If the material evidence alone has potential ambiguities, when coupled with other evidence the narrative accounts describing Candombe and the importance of ceremonial drumming all point to a strong, although perhaps reconstituted, set of African cultural patterns in Buenos Aires that persisted in the nineteenth century and indeed into the twentieth. Schávelzon shows us this nineteenth-century world of the Afro-Porteño, taking this important story of cultural persistence and adaptation right up to the eve of the supposed disappearance of Afro-Argentines at the dawn of the twentieth century.

If Schávelzon's Buenos Aires negra takes us through nineteenth-century Buenos Aires, introducing us in the process to the material record left by that city's Afro-Argentines and to what that record might help reveal about larger cultural and social patterns, Donald Castro's The Afro-Argentine in Argentine Culture: El Negro del Acordeón presents us with another aspect of the cultural record and the problem of its interpretation. His is a concern more familiar to historians trained in the analysis of narrative sources: how might historians make use of fictional representations, whether found in novels, short stories, plays, or poems? Castro integrates these resources

11. See Orser's discussion of this within the context of historical archaeology and its concern with the interpretation of African artifacts. See Orser, "The Archeology of the African Diaspora," 67-69. It is, I think, fair to see an implicit acceptance of Darwinist presumptions on the part of Melville J. Herskovits, an early advocate of the view that there were significant survivals of African culture in the United States as well as elsewhere in the Americas. Herskovits saw the survival of African cultural patterns in the Americas as important in rebutting beliefs in African cultural and biological inferiority. See Melville J. Herskovits, The Myth of the Negro Past (Boston: Beacon Press, 1958) 1-32, passim. 
along with more conventional historiographical tools in order to present a picture of the Afro-Porteño community of the nineteenth century and the first three decades of the twentieth, well after the supposed disappearance had occurred.

Castro is aware that the Afro-Argentine's move toward invisibility involved a complex mixture of political and cultural motivations and not simply the demographic disappearance of received tradition. He places the marginalization of Afro-Argentines within the broader context of elite efforts to marginalize the creole population in the wake of Rosas's downfall. The gaucho, the black, the mulatto, the mestizo, and indeed the uncultivated white creole were to have no place in the new Argentina. For post-Rosas elites, these represented a barbarism to be shed. If the gaucho would become a folkloric national icon in the twentieth century, in the latter half of the nineteenth the elite view was more that of a vagrant and troublemaker and one that was better eliminated. If the Afro-Argentine would in the twentieth century be dimly remembered, if at all, as the faithful retainer to a benevolent white family who loyally rallied to the Argentine colors and conveniently died off in the Paraguayan War of 1865-1870, the elite image in the nineteenth century was less charitable. The Afro-Argentine was still an African, beating drums, dancing Candombe, and polluting castellano with words from the Congo, Angola, and other parts of Africa. Worse, he supported Rosas, a support that Rosas carefully cultivated by attending Afro-Argentine dances, often with his daughter Manuelita.

Immigration was one tool used by Argentine elites to supplant the older, less European, and less civilized population with a new European one. Land bounties and other measures were taken to encourage European immigration. Between 1880 and 1914, Argentina received a greater percentage of European immigrants relative to its base population than any other nation in the Americas. But immigration alone could not fully produce the white or European Argentina desired by those who saw whiteness as essential to national progress. One tool for dealing with African and Indian populations was the census, which was used to redefine people of mixed heritage as white, or in some cases ignored people of African and indigenous heritage altogether. The Census of 1895 illustrates this issue. With its listing of 5,000 blacks in an overall Argentine population of nearly four million, Afro-Argentines should have already been invisible at the end of the nineteenth century. Yet, as George Reid Andrews and others have demonstrated, the Afro-Porteño population was still quite visible, with existing institutions including social clubs and newspapers in turnof-the-century Buenos Aires. ${ }^{12}$

12. Rosenblat, La población indigena, 167. Rosenblat notes in passing that Argentina followed the practice common in other nations of counting as Indians those who were 
It is here that Castro's use of literary sources helps illuminate a world obscured by the official record. There is, of course, for the historian or the social scientist, the always difficult question of how works of fiction might help reveal underlying social reality. One methodological strategy discussed by British social historian Peter Laslett suggests a framework for how Castro's research might be employed. In his article "The Wrong Way through the Telescope: A Note on Literary Evidence in Sociology and Historical Sociology," Laslett notes that it is often the incidental occurrences in works of fiction that can most safely be relied on. He discusses commonplace material aspects of life, those features of a story that provide necessary background in a narrative but are not essential to the central theme that an author might attempt to develop. Laslett illustrates this point with a brief discussion from The Iliad. We can, he tells us, feel reasonably confident that Homer was accurate when he described the crest on Hector's helmet as being made from horse hair. It is this kind of mundane detail that an author in some ways has to get right to gain audience acceptance for larger themes. Laslett's methodological insight might be tentatively extended to characters that repeatedly appear in fictional works. Can the repeated appearance of certain kinds of characters occur if they are essentially missing from the society that the fictional works are portraying? This approach has its dangers, to be sure, but the kind of routine representation of members of ethnic or racial groups in a body of literature at a minimum raises questions and provides suggestions for additional research. ${ }^{13}$

Castro's work forces us to focus on this question because of the persistence of Afro-Argentine characters in early-twentieth-century fiction. The presence of Afro-Argentines in nineteenth-century fiction is, of course, well known and seemingly unremarkable. Black characters played key roles in José Hernández's gaucho epic Martín Fierro, José Mármol's anti-Rosas novel Amalia, and Esteban Echeverría's racist short story "El matadero," but these portrayals were to be expected in a nineteenth-century Argentina where the Afro-American population was still quite visible and readily acknowledged. What Castro shows us is a continued Afro-Argentine presence in various portrayals for the first three decades of the twentieth century. Some of these portrayals were

\footnotetext{
'uncivilized' or who lived in tribal communities. Those who lived outside of tribal communities and had adopted Euro-Argentine culture were considered 'mestizo' regardless of their degree of indigenous ancestry, thus reducing the Indian population of Argentina (168). George Reid Andrews discusses Afro-Argentine social institutions in late nineteenth and early twentieth century Buenos Aires. See Andrews, The Afro-Argentines of Buenos Aires, 178-200, passim.

13. Peter Laslett, "The Wrong Way through the Telescope: A Note on Literary Evidence in Sociology and in Historical Sociology," The British Journal of Sociology vol. 27, no. 3, Special Issue, History and Sociology (Sep., 1976) 319-342 (see 321-322).
} 
doubtlessly holdovers from the nineteenth century. Even at the beginning of the twentieth century, Afro-Argentines still dominated as payadores, experts in the nineteenth-century Argentine art of contrapuntal dueling made famous in Martín Fierro. The most famous payador of the era, an Afro-Argentine named Gabino Ezeiza, was born in Buenos Aires in 1858 and lived in the city until his death in 1916. Castro informs us that Afro-Argentines dominated the genre in the early twentieth century. ${ }^{14}$

A continued Afro-Argentine presence amongst early twentieth-century payadores is not remarkable. What is remarkable is the persistent presence of Afro-Argentines as stock characters in local plays produced in Buenos Aires in the early twentieth century. Castro's work is especially valuable in terms of showing the routine use of Afro-Argentine characters not as exotic elements but as workers, policemen, and other everyday figures in the sainete puppet plays produced by Italian immigrants in La Boca and the other working class neighborhoods where Afro-Argentines and the European immigrants representing the new Argentina mixed at the beginning of the last century. These depictions, Castro tells us, continued well after the First World War. This routine depiction of Afro-Argentine characters by and for an immigrant community that had no memory of the strong Afro-Argentine presence in the nineteenth century serves as an indication that in a number of the working class communities in which the new population of Italian and other European immigrants predominated, the population of African descent was not as absent as the official records tended to indicate.

Castro's work provides a new lens through which to view the issue of Afro-Argentine presence in the twentieth century. Certainly, the evidence he presents from literary sources suggests due caution with respect to what the official sources were telling us about the persistence and significance of the Afro-Argentine population. At times Castro fails to realize the skepticism that his own research suggests. For example, despite the problematic nature of the 1895 census and the fact that his own literary evidence suggests a more significant Afro-Porteño community than that document recorded, Castro nonetheless accepts census data that indicate a turn-of-the-century Afro-Argentine population concentrated in Buenos Aires. While that may have been accurate, the problems Castro's work implies for that census, coupled with the continued presence of significant Afro-mestizo populations in the interior, suggest that the demographic distribution as well as the size of the Afro-Argentine population at the beginning of the twentieth century is still very much an open question.

14. An interesting example in the current renewed interest in Afro-Argentine history is a short profile of Ezeiza that can be found in a community newsletter called La Floresta, representing the Porteño neighborhood where Ezeiza spent most of his life. See "Gabino Ezeiza, payador y cantante," La Floresta. http:/ / www.la-floresta.com.ar/gabino.htm (accessed August 9, 2006). 
Still, Castro has given us a useful history, combining the historian's traditional concerns with political and social conflict with a presentation of materials from literature and popular culture. These tools provide us with a glimpse into another Argentina-one more often obscured than revealed by official sources.

Alejandro Solomianski's prologue in Identidades secretas: La negritud argentina indicates an intimate familiarity with that other Argentina far removed from the nation's traditional middle class, European self-image. His prologue reads, "To my students from 'Fort Apache' who made me understand the true meaning of the word 'nation.'" Fort Apache is a tough, rundown public housing project outside of Buenos Aires. It was built in the late 1940s or early 1950s, judging from a plaque dedicating that low-income housing complex signed by Eva Perón. It is dangerous, so dangerous that it is patrolled by Argentina's Frontier Police armed with shotguns. The project is right next to a villa miseria or shanty town where life must be significantly more desperate. The people in Fort Apache are for the most part mestizos whose Indian ancestry is clearly visible. Some also have visible African ancestry. According to one recent account, 20 percent of Fort Apache's residents are both unemployed and receive no government assistance. ${ }^{15}$

It is that other Argentine reality, the one that is far removed from the heavily promoted European image, the image of Buenos Aires as "the Paris of South America," that Solomianski wants to uncover. He wants to do so through the study of Argentine Negritude, by which he means the depiction of Afro-Argentines in Argentine culture, principally, but not exclusively, in literature. This examination has two aims. The first is the study of Afro-Argentines and their image in the nation's culture. The second aim is a look at what the study of Afro-Argentines might teach us more broadly about subaltern or subordinate groups in Argentine society. Solomianski sees this understanding as critical to an understanding of the Argentine nation and its psychological stake in its construction as a European nation.

Solomianski lays the groundwork for his discussion by reviewing the literature of Afro-Argentine studies and the place of key works in helping to develop and define the field. In that discussion, he spends a little time drawing the boundaries between his work and that of Marvin Lewis, a North American literary scholar who has written on Afro-Argentine literature. Lewis's perspective, Solomianski informs us, is that of a pan-Africanist seeking to place Afro-Argentine literature

15. My observations on "Fort Apache" are based on a visit I made to the community in August 2004. Fort Apache was profiled in the Buenos Aires newspaper El Clarin in March 2005: "Fuerte Apache: Barrio privado." Clarín Edición Domingo 27 March 2005. http: / www. clarin.com/diario/2005/03/27/ sociedad/s-945862.htm (accessed September 2006). 
within a larger context of the literature of what has come to be called the African Diaspora. Solomianski's perspective is that of an Argentinianist seeking to understand and explain the Argentine nation. ${ }^{16}$

Part of the effort to understand the Argentine nation is to realize the importance of the African- and indigenous-descended subaltern groups to the development of the national culture, especially its European consciousness. Solomianski sees race itself as a problematic social construct and argues against essentialist notions that equate Afro-Argentine authorship with representation of Afro-Argentine communities and cultures. He nonetheless sees an understanding of Afro-Argentine culture as important not only in its own right, but also as critical to an understanding of white Argentina as an ideological construct. That construct is a reaction against the pronounced African and Afro-Argentine presence of the nineteenth century. It is part of the nation's striving to be included in the seemingly modern, progressive European world of the twentieth century.

For Solomianski, the Argentine construction of an ideology of whiteness is a national project rooted in the Social Darwinism of the early twentieth century. That project dictated that the Indian and African elements of the population be pushed to the margins of society to be either ignored or at most considered only as exotic oddities. Part of the effort to bring AfroArgentines back to a more central place in their nation's development is a reconsideration of their place in Argentina's history and culture. The history Solomianski presents provides a portrait of slavery far removed from the image of benign paternalism at the periphery of Argentine consciousness. Slavery was brutal. It schooled the slaves in a "pedagogy of fear." The nineteenth-century alliance with Rosas would have longstanding consequences. Anti-Rosas sentiment would be foundational for Saramiento and other architects of the new Argentina of the twentieth century. The link between Rosas and the Afro-Argentine community would exacerbate racism and enhance the determination of Saramiento and other progressive intellectuals to marginalize Afro-Argentines along with mestizos and gauchos, the other elements of the Rosas coalition.

Solomianski uses nineteenth-century Argentine literature to illustrate the importance of the divide between Porteño elites and the creolegaucho masses for the image of Afro-Argentines. Esteban Echeverría's "El matadero" is a plea for the triumph of European enlightenment over African barbarism, as represented by black women working in a butcher shop and fighting dogs for scraps of tripe. Amalia, with its anti-Rosas, antigaucho sentiments, lauds the generosity of white Argentines for being the first in the Americas to free their slaves, while denigrating Afro-Argentine 
servants as informants for Rosas. Martín Fierro, on the other hand, presents its Afro-Argentine characters as sympathetic equals.

Rosas, the visibility of African culture, and the progressive desire to replace the old population with a new one all combined to make AfroArgentines central to the nation's literature in the nineteenth century. That would change in the twentieth century. The emphasis on a European Argentina and the reduced visibility of Afro-Argentines engulfed in a white population swelled by the new immigration combined to push Afro-Argentines to the margins of national writings. Afro-Argentine writers, particularly journalists, existed at the beginning of the century, but they existed largely at the margin of the world of Argentine letters, writing for small community newspapers.

Despite this marginalization, some Afro-Argentines achieved prominence in the first half of the twentieth century as interpreters not of the Afro-Argentine experience, but of Argentine life more generally. Solomianski discusses pioneering film director José Agustin Ferreyra. A mulatto with visible African ancestry, Ferreyra was nicknamed el negro by contemporaries. Considered one of the premier Argentine filmmakers of the early twentieth century, Ferreyra directed Argentine actress Libertad Lamarque in several films and wrote a song recorded by Carlos Gardel. He died in 1943.

It is not the occasional Afro-Argentine success story that is Solomianski's central concern; it is instead the group's marginalization and how that marginalization contributes to our understanding of the Argentine nation. First, Solomianski accepts the view that the Afro-Argentine population is and has been significantly larger than the extrapolations Rosenblat and others have made from the 1895 census. In place of an Afro-Argentine population numbering in the low tens of thousands, Solomianski sees one numbering in the hundreds of thousands. This figure, it should be added, comports with some recent pilot census efforts and the estimates of Afro-Argentine community leaders. ${ }^{17}$ More importantly, Solomianski would urge that

17. Afro-Argentine scholar Miriam Gomes estimates a current Afro-Argentine population of between 500,000 to 800,000. See Miriam Victoria Gomes, "Apuntes para una historia de las instituciones negras en la Argentina: La Población negra en la República Argentina" in Picotti, comp., El negro en la Argentina 401. A pilot census reported in April of 2005 indicated an African-descended population of between 4 and 6 percent of the Argentine total. See "Patricio Downes, "Negros en el pais: Censan cuántos hay y cómo viven" Clarín, 2 April 2005. http:/ / www.clarin.com/diario/2005/04/02/ sociedad/s-04815.htm (accessed September 2006). These figures should be approached with some caution. They partly reflect the difficult question of how to classify people with mixed or multiple ancestries. The tradition in Argentina as in other parts of Latin America has been to differentiate, at least at times, among people of African ancestry categorizing individuals as negro, mulato, trigueño, etc. according to phenotype and ancestry or putative ancestry. Afro-Latin activists in recent decades have called for viewing the population of African descent as a unified group, preferring the term afrodescendiente as more inclusive. Of course many individuals 
negritude, or in the Argentine context, the Afro-American's subaltern status, is a concept that might usefully be extended to other marginalized groups within Argentine society. Solomianski discusses the cabecitas negras (the derogatory term for the migrants, many of them mestizos), who started arriving in Buenos Aires from the Argentine interior in the 1930s. Their numbers became large and noticeable during the 1940s. Perón was linked with this population during his first administration. This migration shocked middle class Porteños. Solomianski argues that in many ways the cabecitas negras are the true "negros" of contemporary Argentina. They, more than those now defined as Afro-Argentines, are the ones who bear the negative stereotypes of the untutored savage, who inhabit the "Fort Apaches" and villas miseria found on the outskirts and within the city limits of Buenos Aires. And although many of them bear clear signs of African as well as Indian ancestry, they are not commonly thought of as part of the Afro-Argentine population. Nonetheless, the term negro is often used to describe them, and Solomianski urges that the very image of otherness displayed in nineteenth-century stories like "El matadero" can help us better understand such subaltern groups in Argentina today.

Whether that is the case remains to be seen. While such a conceptual strategy might usefully link marginalized groups in Argentine society, it also has the potential to obscure important differences between those groups. It also has the potential to once again resubmerge an AfroArgentine population struggling for renewed visibility. Still, Solomianksi's Identidades secretas is sensitive to that struggle, as it is to the significance of the Afro-Argentine presence in the nation's culture. By looking at literature as a mirror of the larger culture, Solomianski helps to shed further light on the recent and indeed current role of people of African descent in Argentine culture.

In places one might have wished for Solomianski to have placed his observations within a larger context. He, like Schávelzon, correctly presents a harsh picture of Argentine slavery. Both critique the older, more indulgent view of the institution. This is a necessary correction, although a recognition that the older, romanticized view of Argentine slavery was, at least in part, based on the contrast between Argentine slavery and the even harsher Brazilian slave regime would have enhanced the discussion of slavery in both books. Yet neither Schávelzon nor Solomianski can be faulted too much in this regard. Their works are addressed to an Argentine audience only dimly aware, if aware at all, of slavery in their nation's past, not to the broader community of students of comparative slavery.

There are other areas that could have been further developed. Solo-

with some or in some cases considerable African ancestry do not wish inclusion, making problematic the question who should or should not be counted in any enumeration of the Afro-Argentine or other Afro-American populations. 
mianski is right to see Rossi's Cosas de negros as a critical text, despite its sometimes problematic tone, but he spends too little time on this text, one of the few early twentieth-century works providing an in-depth overview of the African and Afro-American contribution to Argentine culture. Similarly, Solomianski attacks Marcos de Estrada's Argentinos de origen africano, a collection of short biographical sketches of nineteenth-century Afro-Argentines. Estrada's book mainly focuses on military figures, although it mentions others, including Ezeiza. Solomianski's criticism that Estrada's emphasis on nineteenth-century military figures supported the military dictatorship of the 1970s seems ill founded. Estrada's study instead should properly be seen as part of a longer tradition, in Argentina and elsewhere, of an attempt to make the case for Afro-American acceptability by emphasizing Afro-American service to the nation. It was, as Solomianski informs us, a significant tradition among Afro-Argentine writers at the beginning of the twentieth century. ${ }^{18}$

These criticisms notwithstanding, Solomianski has produced a valuable book that extends the study of Afro-Argentines beyond its usual nineteenth-century precincts into twentieth-century and indeed twentyfirst century Argentina. He does so through an examination of literature as well as other modes of cultural expression, including important discussions of the value of the paintings of Argentine artist Antonio Berni and Uruguayan painter Pedro Figari to the student of Afro-American culture in the Río de la Plata region. ${ }^{19}$

Solomianski's examination of contemporary Afro-Argentine life is short, necessarily so, but it briefly lifts the curtain on the world of twentieth and now twenty-first century Afro-Argentines. It is a world rarely seen by most Argentines and largely unknown outside of Argentina, although it takes place in plain view. As Solomianksi and others have told us, there are now several different Afro-Argentine communities. The creole descendants of nineteenth-century slaves remain in cities such as Buenos Aires, Santa Fe, Salta, and other locations-not in segregated neighborhoods, but in communities where there are visible concentrations. There is evidence, fragmentary to be sure, that some of the nineteenth-century memories and practices persist, unknown to the majority of Argentines but remembered by Afro-Argentines and members of older white families. The descendants of the slaves of the eighteenth and early nineteenth centuries retain their family's memories of Candombe and los barrios del tambor. According to Argentine social anthropologist Alejandro Frigerio, these memories have even sparked

18. Marcos de Estrada, Argentinos de origen africano (Buenos Aires: EUDEBA, 1979).

19. Some of Figari's paintings depicting nineteenth-century Afro-Uruguayan life can be seen in Julio Maria Sanguinetti and Ramiro Casabellas, Figari (Buenos Aires: Museo Nacional de Bellas Artes, N.D.). 
conflict between members of older Afro-Argentine creole communities and more recent Afro-Uruguayan immigrants to Buenos Aires. Artists from both groups claim that theirs is the more authentic representation of the traditional Afro-American arts of the region of the Río de la Plata. ${ }^{20}$ There is also evidence that patron-client relationships between older white and Afro-Argentine families that began in the nineteenth century have persisted into the present. A recent master's thesis in Argentina indicates that the hiring of los negros del congreso is very much governed by the kind of family connections and personal ties that existed at the end of the nineteenth century when the practice began. The extent to which other kinds of interracial linkages have persisted through the twentieth century would be an important topic for further research. ${ }^{21}$

The study of Afro-Argentines is no longer simply the study of the descendants of Argentine slaves and their adaptation to a society that has historically wanted to overlook them. The twentieth and now twentyfirst centuries have added new communities of Afro-Argentines. Cape Verdeans, who began coming to Argentina as part of the Portuguese migration in the 1920s, are one of the more visible groups. With some eight to ten thousand of their members living in the working-class port community of Dock Sud, they represent one of the larger concentrations of people of African descent in contemporary Argentina. Their numbers and visibility in Dock Sud, where Cape Verdeans have a mutual aid society, caused one Argentine journalist to call Dock Sud "an Argentine Harlem." Other groups of people of African descent-Afro-Uruguayans, Afro-Cubans, and Afro-Peruvians as well as Nigerians, Ghanians, and other Africans-have come in recent decades, part of the worldwide migration of peoples from poorer to more prosperous countries. ${ }^{22}$

\section{Frigerio, Cultura negra en el cono sur.}

21. Laura Colabella, "Los negros del congreso": Nombre, filiación y honor en el reclutamiento a la burocracia del poder legislative argentino (master's thesis, Facultad de Humanidades y Ciencias Sociales, Universidad Nacional de Misiones, 2004), 30, 41-42, 57-60, 63, 68-70, 88. One interesting parallel between the nineteenth and twentieth centuries is that Perón, like Rosas, seems to have cultivated Afro-Argentines as part of his broader popular sectors coalition, and that he still retains a popularity amongst some Afro-Argentines. Colabella notes that pictures of both Rosas and Perón can be found in the offices of the congressional servants, Ibid p. 66. In a conversation I had with Horacio Pita (note 2 above) in August 2004, he indicated that as a child in the late 1940s, he saw Juan and Eva Perón attend dances at the "Shimmy Club," an Afro-Argentine dance club that was founded in 1922 and lasted into the 1970s.

22. Simpson, "Porteños de color," 84. Miriam Gomes discusses Cape Verdean organizations in modern Argentina, see Gomes, "Apuntes para una historia de las instituçiones negras en la Argentina," 417-420. Argentine anthropologist Marta Maffia, a specialist on immigration to Argentina, has written about Cape Verdean communities in Argentina. See Maffia, "Acerca de reuniones y festas de cabovereanos en Argentina" in Picotti, AfroArgentine Discourse, 429-454. 
Buenos Aires still has faint echoes of that nineteenth-century world of drums and Candombe. A house in San Telmo that had been a warehouse for slaves about to be sold in nearby Lezama Park had become in 2004 and 2005 when I visited a center for instruction in Afro-American arts, Candombe and capoeira among others. On Sunday evenings AfroUruguayan, or perhaps more properly Afro-Uruguayan-Argentine, drummers temporarily turn Lezama Park into a new barrio del tambores, one now enjoyed by whites as well as people of African descent. On at least one occasion I have seen native-born children of Afro-American immigrants from Uruguay, Cuba, and Peru listening to and playing the drums. They are the new generation of Afro-Argentines. 